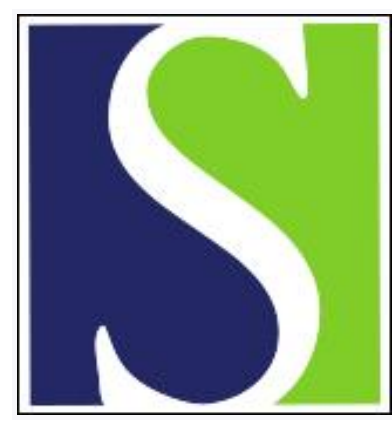

Scand J Work Environ Health 1979;5(4):386-403

https://doi.org/10.5271/sjweh.2653

Issue date: Dec 1979

A simple analytical technique for the determination of hexavalent chromium in welding fumes and other complex matrices.

by Thomsen E, Stern RM

Key terms: analytical technique; autoredox system; chemical analysis; chromium; determination; hexavalent chromium; industrial hygiene; matrix; welding fume

This article in PubMed: www.ncbi.nlm.nih.gov/pubmed/44013 


\title{
A simple analytical technique for the determina- tion of hexavalent chromium in welding fumes and other complex matrices
}

\author{
by EBBE THOMSEN, M.Sc., ${ }^{1}$ and RICHARD M. STERN, Dr.rer.Nat. ${ }^{2}$
}

\begin{abstract}
THOMSEN, E. \& STERN, R. M. A simple analytical technique for the determination of hexavalent chromium in welding fumes and other complex matrices. Scand. j. work environ. \& health 5 (1979) 386-403. A systematic study of analytical methods for the determination of hexavalent chromium showed that currently existing techniques are unsatisfactory when used with welding fumes, the s-diphenylcarbazide method proposed by the U.S. National Institute for Occupational Safety and Health permitting less than $1 \%$ recovery of hexavalent chromium from synthetic welding fumes of known composition. A new (carbonate leaching) technique is proposed which permits better than $80 \%$ recovery of both soluble and insoluble chromium (VI). This technique is then used as part of a general method for the determination of total chemical composition as distributed among sample fractions of different solubility. The method is specifically designed for use in the analysis of small samples and is especially suitable for the routine evaluation of health risks as found in the work environment.
\end{abstract}

Key words: autoredox systems, chemical analysis, chromium, hexavalent chromium, industrial hygiene, welding fumes.

Chromium (Cr) and chromium compounds frequently occur in the work environment and are associated with processes such as the welding and grinding of stainless steel, chrome plating, tanning, wood preserving, painting, and pigment production. Hexavalent chromium $\left(\mathrm{Cr}^{+6}\right)$ compounds are considered to be particularly dangerous, primarily because of the associated risk of allergic reaction and cancer (16).

The analysis of $\mathrm{Cr}^{+6}$ according to the sdiphenylcarbazide (DPC) method (1) and all other previously used techniques is

1 Institute of Technology, Tåstrup, Denmark.

2 The Danish Welding Institute, Glostrup, Denmark.

Reprint requests to: Dr. R. M. Stern, Park Allé 345, Copenhagen, DK-2600 Glostrup, Denmark. often made uncertain by significant interferences from organic components and redox systems in the actual matrix being investigated. This report presents a method for the uncomplicated determination of total $\mathrm{Cr}^{+6}$ content in complex matrices for which other methods have been demonstrated to be inappropriate.

The toxicity of certain chromium compounds has been established for at least 150 years (4). Trivalent chromium $\left(\mathrm{Cr}^{+3}\right)$ is considered to be of very low toxicity, presumably because of the relatively low membrane permeability of this ion. $\mathrm{Cr}^{+6}$ compounds on the other hand exhibit a wide range of toxic potency, presumably because of the ease with which the $\mathrm{Cr}^{+6}$ ion can be absorbed in the alimentary canal and respiratory tract and transported 
across cell membranes. There is at present some degree of uncertainty concerning the carcinogenic properties of $\mathrm{Cr}^{+6}$, primarily because of the difficulty in interpreting human epidemiologic data based on mixed exposure to different types of chromium compounds typical for most industrial situations. Although it has been shown that water-soluble $\mathrm{Cr}^{+6}$ is a mutagen in shortterm in vitro screening tests $(10,15,18,20)$ and a wide range of chromium compounds has produced injection site tumors in experimental animals (17), the NIOSH (National Institute for Occupational Safety and Health) criteria document for recommended exposure levels for $\mathrm{Cr}^{+6}(17)$ and recent, well-documented epidemiologic studies $(7,12,13)$ can be interpreted (21) as strongly indicating that $\mathrm{Cr}^{+6}$ compounds of intermediate solubility are to be considered as suspected potent carcinogens. Highly soluble and highly insoluble chromium may have a relatively low carcinogenic potential for humans $(7,26)$ although the absence of good criteria for defining or identifying individuals exposed to adequately high doses may lead to a general masking effect. For self-evident reasons, the difficulty in measuring insoluble hexavalent chromium in complex substances introduces considerable uncertainty concerning the actual nature of the chromium content of a number of industrial exposures, and this situation increases the difficulty of interpreting epidemiologic data.

It has been established that $\mathrm{Cr}^{+6}$ compounds are biologically active, mutagenic and apparently, as determined by their solubility, carcinogenic, although at present an assignment of carcinogenicity as a function of solubility is still somewhat speculative. This situation leads to considerable uncertainty in the strategies to be used in evaluating and reducing risks to chromium exposure in the work environment, since there is a significant difference in the permitted hygienic levels for exposure to toxic and to carcinogenic material. Threshold limit values (TLVs) for toxic material are typically set at concentrations which experience has shown to result in no observable clinical effects [e.g., $500 \mu \mathrm{g}$ / $\mathrm{m}^{3}$ for $\mathrm{Cr}^{+2}$ and $\mathrm{Cr}^{+3}$ compounds calculated as $\mathrm{Cr}$, and $100 \mu \mathrm{g} / \mathrm{m}^{3}$ for $\mathrm{Cr}^{+6}$ (noncarcinogenic) calculated as chromic oxide $\left.\left(\mathrm{CrO}_{3}\right)\right]$, while those for carcinogens are presently administratively defined as zero, practically determined by the detection limit $\left(1 \mu \mathrm{g} / \mathrm{m}^{3}\right.$ for carcinogenic $\left.\mathrm{Cr}^{+6}\right)$ in order to avoid the current controversy concerning carcinogenic potential at low concentrations.

Welding is a common nonmechanized process whereby copious amounts of fume can be produced locally at high concentrations which present a potentially high hygienic risk. More than $95 \%$ of the fumes are respirable (19), and as much as $38 \%$ of the chromium content is retained after being inhaled (2). Stainless steel fume particles have been identified in lung tissue (25), and magnetic welding fumes of the order of $1-2 \mathrm{~g}$ [typically containing $40 \%$ magnetite $\left(\mathrm{Fe}_{3} \mathrm{O}_{4}\right)$ from mild steel welding] have been found deposited in the respiratory tract of older welders (11). The chemistry of welding fumes is extremely dependent on the welding process, the type of materials used, and the welding parameters chosen. Welding on stainless and other high alloy steel can produce fumes containing up to $25 \%$ chromium, distributed in all possible oxidation states and solubilities. It should also be pointed out that another potential carcinogen, nickel, can be present in concentrations of over $50 \%$ in fumes from certain processes and should therefore be considered in any potential risk assessment.

An evaluation of the risk associated with the chromium content of a particular work environment requires knowledge of the possible compounds contained therein and their respective toxicity and therefore equally requires the existence of analytical techniques to determine quantitatively the composition of the matrix of interest. Welding fumes are a class of material which contains $\mathrm{Cr}^{+6}$ in unpredictable forms in a complex matrix and for which a quantitative analysis has therefore been impossible, especially with respect to the determination of the insoluble $\mathrm{Cr}^{+6}$ content. In particular, calculated hygienic exposure or permitted occupational exposure levels and the relative values for different welding processes and process parameters (i.e., voltage and current) based on the chromium content have been found to depend on the analytical method chosen for the $\mathrm{Cr}^{+6}$ determination. In the following discussion, a simple method for the 
routine determination of $\mathrm{Cr}^{+6}$ in welding fumes is presented, together with a procedure for determining total elemental composition (including $\mathrm{Cr}^{+6}$ ) as a function of solubility (i.e., fractionization) for use with fume quantities typical of normal practice in industrial hygiene situations. It is also shown that the currently recommended procedure for $\mathrm{Cr}^{+6}$ determination, the s-diphenylcarbazide technique of NIOSH (17), is not suitable for use with welding fumes.

\section{ANALYSIS OF HEXAVALENT CHROMIUM IN THE PRESENCE OF REDOX SYSTEMS}

Determination of hexavalent chromium in welding fumes according to known methods

Matrix determined errors. Welding fumes are complicated from both a physical and chemical point of view, and they have been described in detail in terms of analytical chemistry, particle size distribution, and particulate morphology for a series of common welding processes, each of which produces characteristic fumes which can be defined within a wide but finite range of parameters $(22,23)$. For mild (i.e., unalloyed) steel welding, the major component of the fume is $\mathrm{Fe}_{3} \mathrm{O}_{4}$, typically magnetite in crystalline form, while a wide range of other elements appear in often unknown compounds and complexes. Fumes which contain chromium are usually produced by the welding of stainless steels, and they contain, by the nature of the alloys used, iron, nickel, vanadium and other elements which can directly interfere with the $\mathrm{Cr}^{+6}$ determination when it is carried out by the standard DPC method (1). The isolation and extraction of all chromium, followed by a specific determination of chromium content, e.g., by means of atomic absorption spectrophotometry, can be used to eliminate these interferences. Such a method is typically described in the literature for standard methods (3). A method using electron spectroscopy for chemical analysis (ESCA) has been recently proposed for the determina- tion of $\mathrm{Cr}^{+6}$ in welding fumes (14), but it appears to have the significant disadvantage of both interference from other chromium oxidation states and a primary sensitivity to the chemical composition of the surface layer (of the order of $20 \AA$ ) of the fume particles and hence is inappropriate for use on fumes for which homogeneity has not previously been established; the equipment and personnel for such analyses are also not universally available.

Wet chemical analysis of insoluble and slightly soluble chromates normally requires dissolution at a low $\mathrm{pH}$ as the absolute solubility of chromate compounds increases with increasing acid concentration because of the low value of the second ionization constant (K) of chromic acid $\left(\mathrm{K}^{\prime} \simeq 2 \times 10^{-1}, \mathrm{~K}^{\prime \prime} \simeq 4 \times 10^{-7}\right)$ :

$\mathrm{H}^{+}+\mathrm{MeCrO}_{4} \rightleftarrows \mathrm{HCrO}_{4}+\mathrm{Me}^{++}$.

In addition to the interferences which directly affect $\mathrm{Cr}^{+6}$ determination, there exists the risk of change in the oxidation state of the chromium ions during sample preparation with wet chemical methods, which leads to a measured $\mathrm{Cr}^{+6}$ content which does not correspond to the original composition of the sample. Because of the oxidizing potential of $\mathrm{Cr}^{+6}$ and the latent reducing potential of the magnetite present in welding fumes, a change in the oxidation state of the chromium present in the fumes is quite likely. A determination of the $\mathrm{Cr}^{+6}$ content can be either too low or too high, depending on the relative rates of the following reactions:

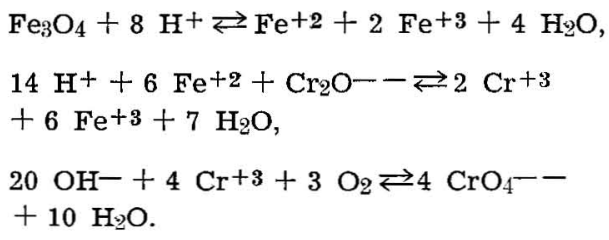

Variation in the oxidation state during analysis will depend on the relative acid concentration and presence of oxidizing or reducing compounds; thus the solubility of the fume components and the $\mathrm{pH}$ used will establish the extent to which the measured $\mathrm{Cr}^{+6}$ content agrees with the actual composition of the fume. The relative solubilities as a function of $\mathrm{pH}$ for several compounds which appear in welding fumes and play a role in equations $b, c$ and $d$ are 
shown in fig. 1 [values from Freier $(8,9)$ ]. It can be seen from fig. 1 and equations $b, c$ and $d$ that the analysis of slightly soluble and insoluble chromates in welding fumes dissolved under highly acidic conditions will be significantly affected by large amounts of $\mathrm{Fe}^{+2}$ from the magnetite present, the low $\mathrm{pH}$ enhancing the reduction of $\mathrm{Cr}^{+6}$. It can therefore be expected that relatively insoluble chromates (with low TLVs) will be found in concentrations which are significantly lower than their actual occurrence in the fumes.

Analysis of hexavalent chromium/chromium in synthetic welding fumes. Synthetic welding fumes having a known chemical composition were analyzed for $\mathrm{Cr}^{+6} / \mathrm{chro}-$ mium as a function of their composition for the purpose of examining the applicability of a number of methods for $\mathrm{Cr}^{+6}$ determination in systems containing chromium in a range of oxidation states in different concentrations and which also contain magnetite in amounts typical for welding fumes. Particular emphasis was placed on determining the effect of $\mathrm{pH}$ on the recovery of highly soluble $\mathrm{Cr}^{+6}$ [in the form of potassium dichromate $\left(\mathrm{K}_{2} \mathrm{Cr}_{2} \mathrm{O}_{7}\right)$ ] and insoluble $\mathrm{Cr}^{+6}$ [in the form of lead chromate $\left.\left(\mathrm{PbCrO}_{4}\right)\right]$.

The solid samples were prepared for analysis by heating to the boiling point with the appropriate solvent, as recommended by three common techniques (a) $0.5 \mathrm{n}$ sulfuric acid [as recommended by NIOSH (17)], (b) a sodium acetate buffer [as suggested by Blomquist (5)], and (c) demineralized water. The filtrate was analyzed for chromium by atomic absorption, and in certain cases for $\mathrm{Cr}^{+6}$ by the DPC method, a single determination being made in each case. The results of the chromium and $\mathrm{Cr}^{+6}$ recovery, for different compositions, as a function of the preparation $\mathrm{pH}$ and analysis technique are shown schematically in fig. 2.

For pure, highly soluble chromate $\left(\mathrm{K}_{2} \mathrm{Cr}_{2} \mathrm{O}_{7}\right)$, there was good agreement between the $\mathrm{Cr}^{+6}$ content as determined by

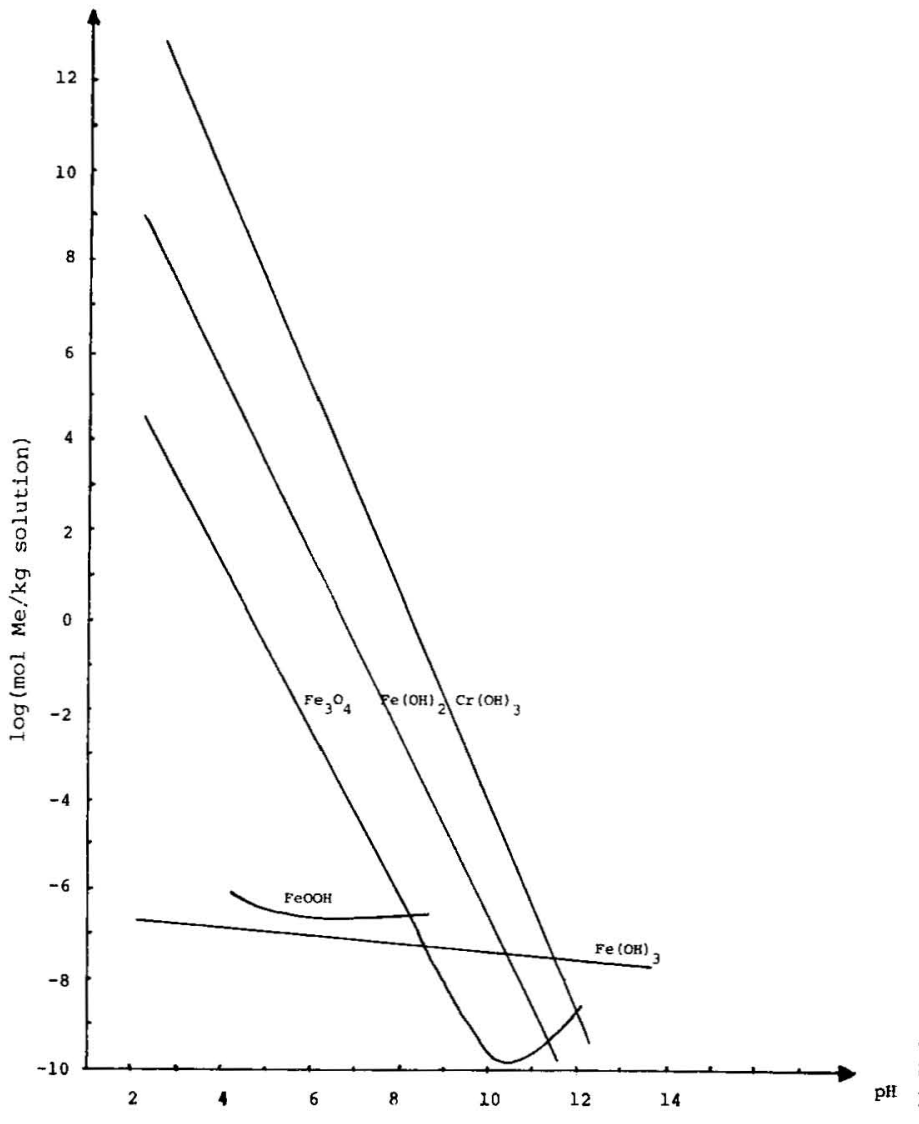

Fig. 1. Solubilities of some possible constitutents of welding fumes as a function of $\mathrm{pH}$. 
the DPC method and total chromium as determined by atomic absorption spectrometry (AAS), recovery being greater than $95 \%$ independent of the solution $\mathrm{pH}$. As expected, the insoluble chromate was only dissolved and could only be recovered at a low $\mathrm{pH}$; for $\mathrm{pH}>4$ less than $10 \%$ of the original chromium was recovered, the two methods giving identical results. With an acidic solution $75 \%$ of the chromium was recovered with the DPC method, and $98 \%$ by AAS.

In the presence of magnetite, less than $1 \%$ of the insoluble chromate appeared (as $\mathrm{Cr}^{+6}$ ) in solution, both AAS and DPC methods giving the same low value; the rest remained undissolved and hence undetected. At a low $\mathrm{pH} 98 \%$ of the chromium could be recovered, reduced to $\mathrm{Cr}^{+3}$ as detected by AAS; the DPC method showed less than $1 \% \mathrm{Cr}^{+6}$. Although the total chromium could be determined independently of $\mathrm{pH}$ by use of AAS, for the soluble chromate, in the presence of magnetite, at least $10 \%$ of the $\mathrm{Cr}^{+6}$ was reduced even at neutral pH (only $90 \%$ being recovered by the DPC method); the $\mathrm{Cr}^{+6}$ was found to be completely reduced upon acid solution (essentially zero recovery with the DPC method).

In addition to the synthetic welding fumes, the analysis of which is presented in fig. 1, similar studies were made of a series of samples containing an extended range of $\mathrm{Cr}^{+6}$ compounds of different solubilities [calcium chromate $\left(\mathrm{CaCrO}_{4}\right)$, zinc chromate $\left.\left(\mathrm{ZnCrO}_{4}\right)\right]$, together with $\mathrm{Cr}+\mathbf{3}$ [as chromic chloride $\left.\left(\mathrm{CrCl}_{3}\right)\right]$. The composition of the entire series of synthetic welding fumes, together with the appropriate analysis results, are presented in table 1. An examination of table 1 shows that insoluble $\mathrm{Cr}^{+6}$ compounds cannot be determined in synthetic welding fumes by means of the DPC method, as the presence of magnetite leads to a reduction of the dissolved $\mathrm{Cr}^{+6}$ by more than $99 \%$. It can also be seen that the solubility of chromium compounds appears to be reduced by the presence of magnetite,

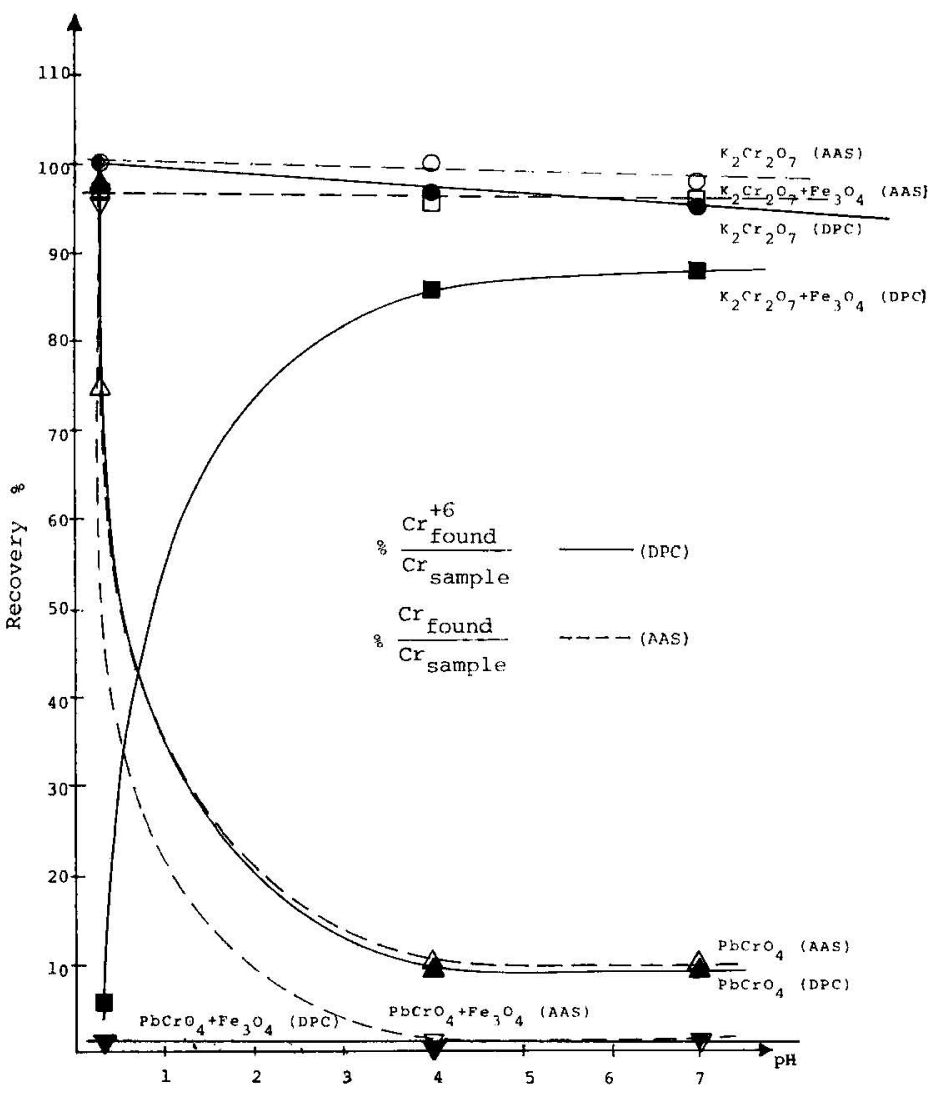

Fig. 2. Chromium recovery for different sample compositions as a function of $\mathrm{pH}$. Atomic absorption spectroscopy (AAS) - _ - ; s-diphenylcarbazide method (DPC) 
presumably due to the basic character of the magnetite (in spite of the presence of the sodium acetate buffer). The presence of $\mathrm{Cr}^{+3}$ was not found to interfere with the $\mathrm{Cr}^{+6}$ determination, the $\mathrm{Cr}^{+3}$ appearing however in the total chromium content, as determined by the AAS method.

Nonapplicability of known analytical methods for hexavalent chromium in welding fumes. From the preceding discussion it can be concluded that the DPC method, both as recommended by NIOSH (17) or as modified by Blomquist (5), is a satisfactory technique for $\mathrm{Cr}^{+0}$ determination, provided direct and indirect interferences can be eliminated, and is especially useful when the sample contains only $\mathrm{Cr}^{+6}$. If this is known to be the case, however, then simple AAS is as satisfactory.

In the case of complex samples such as welding fumes which contain reducing/ oxidizing substances, there is the possibility of interference from metals which form colored complexes with DPC, as well as the probability of changes in the original $\mathrm{Cr}^{+6}$ concentration during analysis. This latter problem is enhanced by the low $\mathrm{pH}$ required for the DPC reaction itself, and also by the low $\mathrm{pH}$ frequently required for sample solution, especially for those solutions containing chromates of low solubility (fig. 2). The presence of magnetite in most welding fume samples insures that almost all of the slightly soluble $\mathrm{Cr}^{+6}$ eventually dissolved will be reduced before measurement. The DPC method, as other wet chemical methods, cannot be used for $\mathrm{Cr}^{+6}$ determination in either welding fumes or other samples for which the necessary sample preparation liberates latent redox processes present in the matrix.

Table 1. Results of chromium analyses of synthetic welding fumes of different chemical compositions with atomic absorption spectrometry (AAS) and the s-diphenylcarbazide (DPC) method.

\begin{tabular}{|c|c|c|c|c|c|c|c|c|c|}
\hline \multirow{4}{*}{$\begin{array}{l}\text { Sample } \\
\text { no. }\end{array}$} & \multirow{2}{*}{\multicolumn{4}{|c|}{ Composition }} & \multirow{4}{*}{ Preparation } & \multicolumn{4}{|c|}{ Results } \\
\hline & & & & & & \multicolumn{2}{|c|}{ AAS } & \multicolumn{2}{|c|}{ DPC } \\
\hline & \multicolumn{2}{|r|}{$\mathrm{MeCrO}_{4}$} & \multirow{2}{*}{$\frac{\mathrm{CrCl}_{3}}{\mathrm{mg} \mathrm{Cr+3)}}$} & \multirow{2}{*}{$\begin{array}{l}\mathrm{Fe}_{3} \mathrm{O}_{4} \\
\text { (mg) }\end{array}$} & & Found & $\overline{\text { Recovery }}$ & Found & Recovery \\
\hline & $\mathrm{Me}$ & $(\mathrm{mg} \mathrm{Cr}+6)$ & & & & ( $\mathrm{mg} \mathrm{Cr})$ & $(\% \mathrm{Cr})$ & $(\mathrm{mg} \mathrm{Cr}+6)$ & $(\% \mathbf{C r}+\mathbf{6})$ \\
\hline 1 & $\mathrm{~Pb}$ & 8.7 & 0 & 0 & $0.5 \mathrm{n}$ sulfuric acid & 8.4 & 98 & 6.4 & 74 \\
\hline 2 & $\mathrm{~Pb}$ & 9.9 & 0 & 1,000 & $0.5 \mathrm{n}$ sulfuric acid & 9.5 & 96 & 0.1 & 1 \\
\hline 3 & $\mathrm{~Pb}$ & 8.1 & 59.0 & 0 & $0.5 \mathrm{n}$ sulfuric acid & 65.0 & 97 & - & - \\
\hline 4 & $\mathrm{~Pb}$ & 8.4 & 74.2 & 1,000 & $0.5 \mathrm{n}$ sulfuric acid & 81.0 & 98 & - & - \\
\hline 5 & $\mathrm{Ca}$ & 15.5 & 0 & 0 & $0.5 \mathrm{n}$ sulfuric acid & 15.5 & 100 & - & - \\
\hline 6 & $\mathrm{Zn}$ & 12.5 & 0 & 0 & $0.5 \mathrm{n}$ sulfuric acid & 12.5 & 100 & - & - \\
\hline 7 & $\mathrm{~K}^{\mathrm{a}}$ & 17.6 & 0 & 0 & $0.5 \mathrm{n}$ sulfuric acid & 17.4 & 98 & - & - \\
\hline 8 & $\mathrm{~K}^{\mathrm{a}}$ & 10.1 & 0 & 0 & $0.5 \mathrm{n}$ sulfuric acid & 10.3 & 102 & 10.1 & 100 \\
\hline 9 & $\mathrm{~K}^{\mathrm{a}}$ & 10.5 & 0 & 1,000 & $0.5 \mathrm{n}$ sulfuric acid & 10.2 & 97 & 0.6 & 6 \\
\hline 10 & $\mathrm{~K}^{\mathrm{a}}$ & 17.4 & 35.6 & 0 & $0.5 \mathrm{n}$ sulfuric acid & 51.9 & 98 & - & - \\
\hline 11 & $\mathrm{~Pb}$ & 8.4 & 0 & 0 & $\begin{array}{l}\text { Sodium acetate } \\
\text { buffer pH } 4 \\
\text { Sodium acetate }\end{array}$ & 0.7 & 8 & 0.8 & 10 \\
\hline 12 & $\mathrm{~Pb}$ & 8.8 & 0 & 1,000 & $\begin{array}{l}\text { buffer pH } 4 \\
\text { Sodium acetate }\end{array}$ & 0.06 & 1 & 0.006 & 0 \\
\hline 13 & $\mathrm{~Pb}$ & 3.8 & 0 & 0 & $\begin{array}{l}\text { buffer } \mathrm{pH} \mathbf{4}^{\mathrm{b}} \\
\text { Sodium acetate }\end{array}$ & 0.4 & 10 & 0.39 & 10 \\
\hline 14 & $\mathrm{~K}^{\mathbf{a}}$ & 10.3 & 0 & 0 & $\begin{array}{l}\text { buffer pH } 4 \\
\text { Sodium acetate }\end{array}$ & 10.3 & 100 & 9.98 & 97 \\
\hline 15 & $\mathrm{~K}^{\mathrm{a}}$ & 9.4 & 0 & 1,000 & buffer $\mathrm{pH} 4$ & 9.0 & 96 & 8.1 & 86 \\
\hline 16 & $\mathrm{~Pb}$ & 8.1 & 0 & 0 & Demineralized water & 0.72 & 9 & 0.83 & 10 \\
\hline 17 & $\mathrm{~Pb}$ & 8.4 & 0 & 1,000 & Demineralized water & 0.06 & 1 & 0.06 & 1 \\
\hline 18 & $\mathrm{~Pb}$ & 8.3 & 55.4 & 0 & Demineralized water & 50.0 & 78 & - & $\ldots$ \\
\hline 19 & $\mathrm{~Pb}$ & 9.6 & 64.2 & 1,000 & Demineralized water & 57.0 & 77 & - & - \\
\hline 20 & $\mathrm{~K}^{\mathrm{a}}$ & 9.3 & 0 & 0 & Demineralized water & 9.15 & 98 & 8.80 & 95 \\
\hline 21 & $\mathrm{~K}^{\mathrm{a}}$ & 9.7 & 0 & 1,000 & Demineralized water & 9.35 & 96 & 8.50 & 88 \\
\hline
\end{tabular}

a As potassium dichromate.

b Cold extraction. 
The alternative physical-chemical methods, such as ESCA, although not presenting a risk with respect to variation of the $\mathrm{Cr}^{+6}$ oxidation state during measurement, would appear inappropriate for routine investigations of welding fumes or for the quantitative determination of inhomogeneous samples with a low $\mathrm{Cr}^{+6}$ content. Thus there would appear at present to be no published technique for the routine evaluation of the $\mathrm{Cr}^{+6}$ risk present in common industrial exposures in general and welding fumes in particular.

Analysis of total hexavalent chromium in welding fumes

Requirements of the analytical method. An acceptable method for the determination of $\mathrm{Cr}^{+6}$ in welding fumes must provide for complete leaching of all $\mathrm{Cr}^{+6}$ from the sample matrix without liberating any latent oxidation or reduction potential and thereby permit a quantitative determination of the undisturbed original $\mathrm{Cr}^{+6}$ content. If used as a basis for risk evaluation in the work environment, the method must have a sufficiently low detection limit so as to permit significant measurements in typical samples containing $\mathrm{Cr}^{+6}$ at or below the permitted hygienic exposure levels. Furthermore, it is desirable that the technique be able to separate the $\mathrm{Cr}^{+6}$ detected into several intervals of varying toxicity such as might be determined by fractions of varying relative solubility.

Analytical principles. It has been demonstrated that the currently available analytical methods utilizing acidic to neutral sample preparation all suffer from the disadvantage of the reduction of a large fraction of the $\mathrm{Cr}^{+6}$ content of the synthetic welding fume samples tested. With alkaline leaching, however, only a very small amount of the reducing component of the welding fumes (in this case $\mathrm{Fe}^{+2}$ ) will be liberated and in quantities insignificant when compared to $\mathrm{Cr}^{+6}$, so that no reduction should take place. This phenomenon can be seen from fig. 1, which illustrates the fact that the solubility of ferro compounds at $\mathrm{pH} 11$ is approximately $10^{-15}$ of that at $\mathrm{pH}$. The solubility of the
$\mathrm{Ni}^{+2}, \mathrm{Cr}^{+3}$, and many other metals contained in the welding fumes will similarly disappear at a high $\mathrm{pH}$. Slightly soluble or insoluble $\mathrm{Cr}^{+6}$ compounds which do not contain amphoteric ions will however in general be insoluble at a high $\mathrm{pH}$ as well.

The current work describes a method for the solution of chromates at a high $\mathrm{pH}$ by means of carbonate leaching, a technique which is generally used for the leaching of insoluble sulfates. The method is described by the following reaction:

$\mathrm{MeCrO}_{4}+\mathrm{CO}_{3}--\rightleftarrows \mathrm{MeCrO}_{3}+\mathrm{CrO}_{4}--$.

In the presence of a large excess of carbonate, equilibrium is shifted quantitatively to the right, insoluble chromates becoming transformed to insoluble carbonates and dissolved chromate. The necessary carbonate excess is determined by the solubility product of the material used, since, following equation e, equilibrium is described by:

$$
\begin{aligned}
& \frac{\left[\mathrm{MeCO}_{3}\right] \cdot\left[\mathrm{CrO}_{4}--\right]}{\left[\mathrm{MeCrO}_{4}\right] \cdot\left[\mathrm{CO}_{3}--\right]}=\mathrm{K}_{1} \\
& \text { or } \\
& \frac{\left[\mathrm{CO}_{3}--\right]}{\left[\mathrm{CrO}_{4}--\right]}=\frac{1}{\mathrm{~K}_{1}} \frac{\left[\mathrm{MeCO}_{3}\right]}{\left[\mathrm{MeCrO}_{4}\right]}=\mathrm{K},
\end{aligned}
$$

where with the use of the solubility products defined by:

$\mathrm{L}_{\mathrm{Me}\left(\mathrm{O}_{3}\right.}=\left[\mathrm{Me}^{++}\right]\left[\mathrm{CrO}_{4}--\right]$

and

$\mathrm{L}_{\mathrm{He}^{+} \mathrm{Cr}_{4}}=\left[\mathrm{Me}{ }^{++}\right]\left[\mathrm{CO}_{3}--\right]$,

and, following equations $\mathrm{g}, \mathrm{h}$ and $\mathrm{i}$,

$\frac{\left[\mathrm{CO}_{3}--\right]}{\left[\mathrm{CrO}_{4}--\right]}=\mathrm{K}=\frac{\mathrm{L}_{\mathrm{MeC}} \mathrm{C}_{3}}{\mathrm{~L}_{\mathrm{MeC} \mathrm{rO}}}$.

The entire chromate content of the sample can be expected to go into solution as soon as the carbonate concentration becomes $\mathrm{K}$ times the expected chromium content.

Based on the solubility products given by Freier $(8,9)$, the approximate $\mathrm{K}$ values for the conversion of lead chromate $\left(\mathrm{PbCrO}_{4}\right)$ and silver chromate $\left(\mathrm{Ag}_{2} \mathrm{CrO}_{4}\right)$ are calculated to be $\mathrm{K}_{\mathrm{I} b}=1.86$ and $\mathrm{K}_{\mathrm{Ag}}$ $=1.54$. When the relatively small amounts of chromium expected to be found in welding fumes are considered, there should be no difficulty in establishing the necessary excess of carbonate required. 
The preceding discussion provides the theoretical principle used in the analytical method. Because of the temperature dependence of the solubility products and equilibrium constants involved and the possibility of the formation of oxides, hydroxides, and various other basic compounds and complexes in place of carbonates, a quantitative theoretical treatment of the actual situation during analysis is extremely difficult to perform.

Procedure for determination of total hexavalent chromium by the carbonate method. Total $\mathrm{Cr}^{+\boldsymbol{b}}$ is determined by the carbonate method as follows: (a) the sample is weighed in a beaker, (b) $50.0 \mathrm{ml}$ of $7 \%$ sodium carbonate is added, (c) the sample is warmed to boiling, (d) the sample is left to cool, (e) the precipitate is removed by filtration, and finally (f) the filtrate is analyzed directly for $\mathrm{Cr}^{+6}$.

Analysis of hexavalent chromium/chromium in synthetic welding fumes by the carbonate method. Synthetic welding fumes having a wide variety of known chemical compositions were analyzed according to the carbonate method just described. Samples were produced consisting of varying amounts of chromates of different solubility (lead, calcium, zinc, silver and potassium chromate) mixed with a range of concentrations of $\mathrm{Cr}^{+3}$ (as $\mathrm{CrCl}_{3}$ ) and $\mathrm{Fe}_{3} \mathrm{O}_{4}$.

Some of the filtrates were also analyzed by the DPC method for $\mathrm{Cr}^{+6}$. In general it was found that all the pure chromates studied were dissolved in the carbonate method and that the chromium content determined directly by AAS was identical to that expected for $\mathrm{Cr}^{+6}$ to within about $10 \%$. Large concentrations of $\mathrm{Cr}^{+3}$ did not interfere with the recovery. In the presence of magnetite, however, somewhat less $\mathrm{Cr}^{+6}$ was recovered than the amount originally contained in the samples, the recovery rate depending partly on the chromate examined and partly on the amount of magnetite present. The analysis of silver chromate appeared to show a systematic error of unknown origin that led to a recovery of $110 \%$. With a single exception (a zinc chromate sample containing large amounts of magnetite and $\mathrm{Cr}^{+3}$ ), recovery was always between $75-110 \%$ of the original $\mathrm{Cr}^{+6}$ content. The systematic behavior of the $\mathrm{Cr}^{+6}$ recovery as a function of magnetite for different chromates is shown in fig. 3, and the results of the entire series of measurements are assembled in table 2. All measurements were made in single determinations.

\section{DISCUSSION OF THE CARBONATE METHOD}

\section{Detection limits and recovery}

The carbonate method can provide a technique for the rapid and simple determination of total hexavalent chromium in welding fumes and is, in this respect, unique when compared to other current methods. It can be used for routine measurements on standard hygienic samples (i.e., Millipore filters). At lower concentrations, the sensitivity can be increased by the use of flameless atomic absorption techniques or the use of a smaller solution volume. With low loading, as little as $0.8 \mu \mathrm{g}$ was detected on such a filter, a level corresponding to a sample obtained under normal

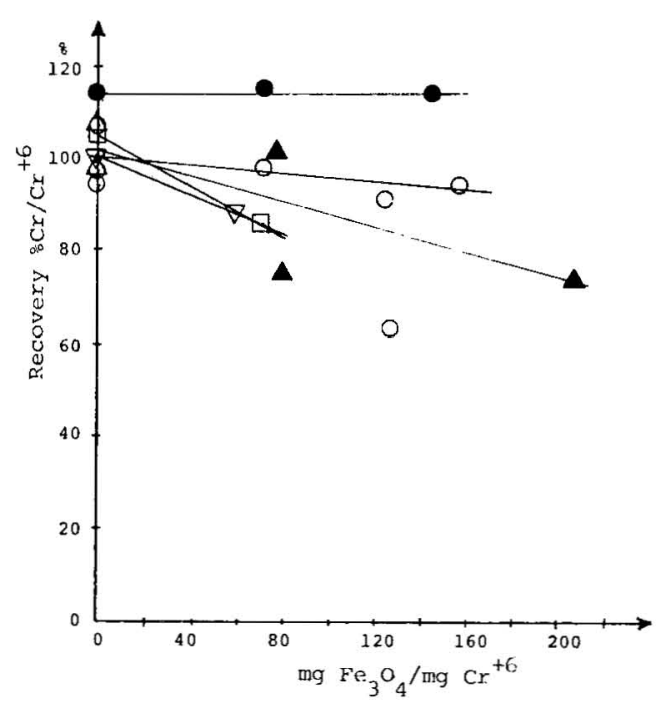

Fig. 3. Recovery of lead (O), zinc (A), cadmium $(\square)$, potassium $(\nabla)$, and silver $(\bullet)$ chromate as a function of magnetite content. 
conditions for exposure $\left(0.8 \mathrm{~m}^{3}\right)$ at the proposed NIOSH limit $\left(1 \mu \mathrm{g} / \mathrm{m}^{3} \mathrm{Cr}^{+6}\right)$. The sensitivity, recovery, and uncertainty of the method are within the limits normally associated with measurements made in the work environment.

The influence of the carbonate method on the stability of redox systems

The effectiveness of the carbonate method is somewhat dependent on the redox properties of the sample and can without doubt be further optimized. In welding fumes the $\mathrm{Cr}^{+6}$ determination is principally disturbed by the presence of $\mathrm{Fe}^{+3 / \mathrm{Fe}^{+2}}$, which for the carbonate method can be described by the following redox equation:

$\mathrm{Cr}(\mathrm{OH})_{3}+5 \mathrm{OH}^{-}+3 \mathrm{Fe}^{+++\rightleftarrows} \mathrm{CrO}_{4}--$ $+4 \mathrm{H}_{2} \mathrm{O}+3 \mathrm{Fe}^{++}$.
Equilibrium conditions can be evaluated with the help of calculating for the appropriate electrochemical cell as follows:

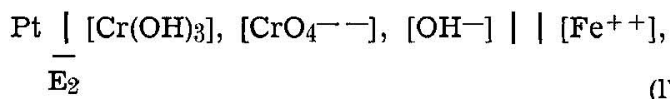

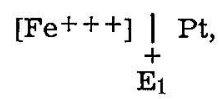

Following Nernst's equation

$\mathbf{E}_{1}=\mathrm{E}_{1} 0+\frac{0.0591}{3} \log \frac{\left[\mathrm{CrO}_{4}--\right]}{\left[\mathrm{Cr}(\mathrm{OH})_{3}\right][\mathrm{OH}-]^{5}} \quad(\mathrm{~m})$ and

$\mathbf{E}_{2}=\mathbf{E}_{2^{0}}+0.0591 \log \frac{\left[\mathrm{Fe}^{+++}\right]}{\left[\mathrm{Fe}^{++}\right]}$

such that

$\mathbf{E}=\mathbf{E}_{2}-\mathbf{E}_{1}=\mathbf{E}_{2} 0-\mathbf{E}_{1} \mathbf{0}+0.0591 \log$

$\frac{\left[\mathrm{Fe}^{+++]}\right.}{\left[\mathrm{Fe}^{++}\right]}-0.0197 \log \frac{\left[\mathrm{CrO}_{4}--\right]}{\left[\mathrm{Cr}(\mathrm{OH})_{3}\right][\mathrm{OH}-]^{5}}$

where $E_{1}{ }^{0}=0.13 \mathrm{~V}$ and $E_{2} 0=0.770 \mathrm{~V}$ are

Table 2. Results of chromium analyses of synthetic welding fumes of different chemical compositions with the carbonate method.

\begin{tabular}{|c|c|c|c|c|c|c|c|c|c|}
\hline \multirow{4}{*}{$\begin{array}{c}\text { Sample } \\
\text { no. }\end{array}$} & \multicolumn{5}{|c|}{ Composition } & \multicolumn{4}{|c|}{ Results } \\
\hline & \multirow{2}{*}{\multicolumn{2}{|c|}{$\mathrm{MeCrO}_{4}$}} & \multirow{3}{*}{$\begin{array}{c}\mathrm{CrCl}_{3} \\
\underset{\mathrm{Cr}}{\mathrm{mg}}\end{array}$} & \multirow{2}{*}{\multicolumn{2}{|c|}{$\mathrm{Fe}_{3} \mathrm{O}_{4}$}} & \multicolumn{2}{|r|}{ AAS } & \multicolumn{2}{|c|}{$\mathrm{DPC}$} \\
\hline & & & & & & \multirow{2}{*}{$\begin{array}{l}\text { Found } \\
\text { (mg Cr) }\end{array}$} & \multirow{2}{*}{$\begin{array}{c}\text { Recovery } \\
(\% / 0 \mathrm{Cr} / \\
\mathrm{Cr}+6)\end{array}$} & \multirow{2}{*}{$\begin{array}{l}\text { Found } \\
(\mathrm{mg} \\
\mathrm{Cr}+6)\end{array}$} & \multirow{2}{*}{$\begin{array}{c}\text { Recovery } \\
(\% / \mathrm{Cr} / \\
\mathrm{Cr}+6)\end{array}$} \\
\hline & $\mathrm{Me}$ & $\mathrm{mg} \mathrm{Cr}+6$ & & $\mathrm{mg}$ & $\underset{\mathrm{Cr}+6}{\mathrm{mg} / \mathrm{mg}}$ & & & & \\
\hline 22 & $\mathrm{~Pb}$ & 9.7 & 0 & 0 & & 9.4 & 97 & 9.9 & 102 \\
\hline 23 & $\mathrm{~Pb}$ & 8.2 & 0 & 0 & & 7.7 & 94 & - & - \\
\hline 24 & $\mathrm{~Pb}$ & 71.0 & 0 & 0 & & 75.8 & 107 & & \\
\hline 25 & $\mathrm{~Pb}$ & 7.9 & 0 & 1,000 & 126.6 & 5.0 & 63 & 5.3 & 67 \\
\hline 26 & $\mathrm{~Pb}$ & 8.1 & 0 & 1,000 & 123.5 & 7.4 & 91 & & \\
\hline 27 & $\mathrm{~Pb}$ & 70.3 & 0 & 5,000 & 71.1 & 68.8 & 98 & & \\
\hline 28 & $\mathrm{~Pb}$ & 71.5 & 0 & 11,200 & 156.6 & 67.5 & 94 & & \\
\hline 29 & $\mathrm{~Pb}$ & 9.1 & 49.7 & 0 & & 8.1 & 89 & & \\
\hline 30 & $\mathrm{~Pb}$ & 70.3 & 3.63 & 0 & & 78.0 & 111 & & \\
\hline 31 & $\mathrm{~Pb}$ & 9.2 & 41.3 & 1,000 & & 5.9 & 64 & & \\
\hline 32 & $\mathrm{~Pb}$ & 8.2 & 43.2 & 1,000 & & 7.5 & 92 & & \\
\hline 33 & $\mathrm{~Pb}$ & 69.1 & 4.06 & 5,000 & & 68.2 & 99 & & \\
\hline 34 & $\mathrm{Ca}$ & 14.5 & 0 & 0 & & 15.3 & 106 & & \\
\hline 35 & $\mathrm{Ca}$ & 14.0 & 0 & 1,000 & 71.4 & 12.0 & 86 & & \\
\hline 36 & $\mathrm{Zn}$ & 12.3 & 0 & 0 & & 12.0 & 98 & & \\
\hline 37 & $\mathrm{Zn}$ & 48.2 & 0 & 0 & & 51.8 & 108 & & \\
\hline 38 & $\mathrm{Zn}$ & 12.5 & 0 & 1,000 & 80 & 9.4 & 75 & & \\
\hline 39 & $\mathrm{Zn}$ & 49.6 & 0 & 5,000 & 100.8 & 38.7 & 78 & & \\
\hline 40 & $\mathrm{Zn}$ & 48.1 & 0 & 10,000 & 207.9 & 35.2 & 73 & & \\
\hline 41 & $\mathrm{Zn}$ & 12.5 & 58.8 & 0 & & 12.5 & 100 & & \\
\hline 42 & $\mathrm{Zn}$ & 11.8 & 73.2 & 1,000 & & 5.1 & 43 & & \\
\hline 43 & $\mathrm{Ag}_{2}$ & 71.3 & 0 & 0 & & 81.2 & 114 & & \\
\hline 44 & $\mathrm{Ag}_{2}$ & 70.5 & 0 & 5,000 & 70.9 & 80.7 & 115 & & \\
\hline 45 & $\mathrm{Ag}_{2}$ & 69.1 & 0 & 10,000 & 144.7 & 78.9 & 114 & & \\
\hline 46 & $\mathrm{~K}_{2}$ & 17.4 & 0 & 0 & & 17.6 & 101 & & \\
\hline 47 & $\mathbf{K}_{2}$ & 17.0 & 0 & 1,000 & 58.8 & 15.0 & 88 & & \\
\hline
\end{tabular}


the standard potentials for electrodes 1 and 2, respectively, according to Freier (8).

$\mathrm{E}=0.640+0.0591 \log \frac{\left[\mathrm{Fe}^{+++}\right]}{\left[\mathrm{Fe}^{++}\right]}-0.0197$

$\log \frac{\left[\mathrm{CrO}_{4}--\right]}{\left[\mathrm{Cr}(\mathrm{OH})_{3}\right]}+0.0985 \log [\mathrm{OH}-]$

or

$\mathrm{E}=-0.739+0.0591 \log \frac{\left[\mathrm{Fe}^{+++}\right]}{\left[\mathrm{Fe}^{++}\right]}-0.0197$

$\log \frac{\left[\mathrm{CrO}_{4}-\right]}{\left[\mathrm{Cr}(\mathrm{OH})_{3}\right]}+0.0985 \mathrm{pH}$.

Under equilibrium $\mathrm{E}=0$ equation $q$ can be rewritten as

$\log \frac{\left[\mathrm{CrO}_{4}--\right]}{\left[\mathrm{Cr}(\mathrm{OH})_{3}\right]}=5.00 \mathrm{pH}+3.00 \log$

$\frac{\left[\mathrm{Fe}^{+++}\right]}{\left[\mathrm{Fe}^{++}\right]}-37.51$.

(r)

If the carbonate method is used with a welding fume matrix composed primarily of chromium and magnetite the concentrations $\mathrm{Fe}^{+3 / \mathrm{Fe}^{+2}}$ will be determined by the $\mathrm{pH}$ of the solution as in fig. 1 and lead to:

$\log \frac{\left[\mathrm{CrO}_{4}--\right]}{\left[\mathrm{Cr}(\mathrm{OH})_{3}\right]}=\mathrm{f}(\mathrm{pH})$.

(s)

This function $\mathrm{f}(\mathrm{pH})$ is sketched in fig. 4 . It can be seen that a given concentration ratio $\mathrm{Cr}^{+6} / \mathrm{Cr}^{+3}$ will be in stable equilibrium at only one specific $\mathrm{pH}$, which is then defined as optimal for the preparation of that sample. At a higher $\mathrm{pH}$, the system will move towards a higher $\mathrm{Cr}^{+6} / \mathrm{Cr}^{+3}$ ratio and a tendency for the oxidation of $\mathrm{Cr}^{+3}$ to $\mathrm{Cr}^{+6}$ is implied. At a $\mathrm{pH}$ lower than optimum, the system will tend to move in the other direction, and $\mathrm{Cr}^{+6}$ will be converted to $\mathrm{Cr}^{+3}$. The establishment of a stable equilibrium will depend somewhat on the reaction rate of the system, which is a further function of temperature and concentration. Calculating the reaction rates for the system under consideration has proved to be extremely difficult. In general one can expect that $\mathrm{Cr}^{+3}$ reacts more slowly than $\mathrm{Cr}^{+6}$ and that $\mathrm{Cr}^{+3}$, especially at a high $\mathrm{pH}$, will be bound in basic polymeric compounds.

\section{Alkaline fusion}

Velocity constants have extremely high values during fusion, which should be ac-

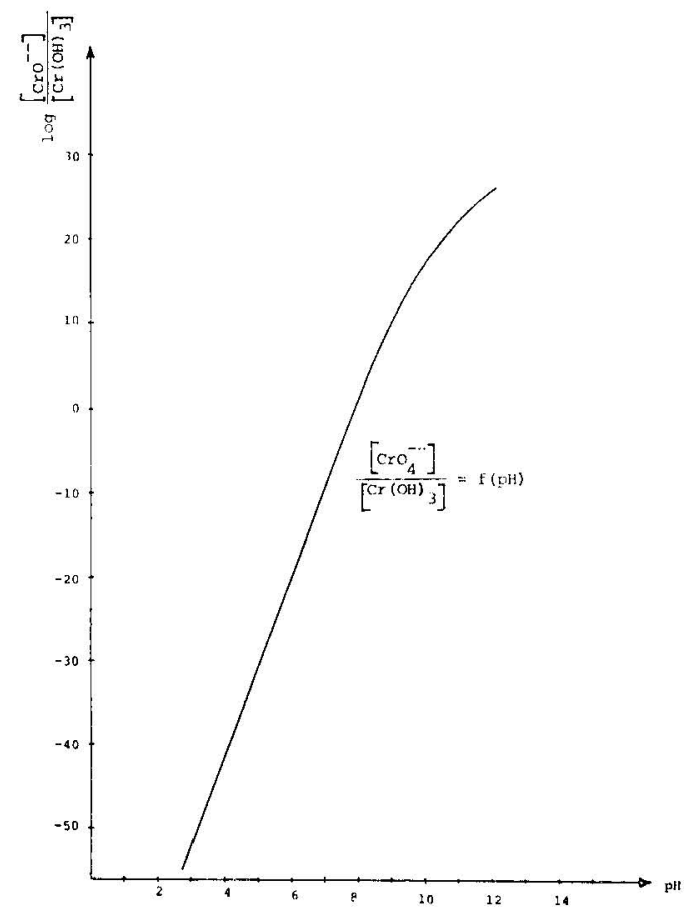

Fig. 4. Relative distribution of $\mathrm{Cr}+6$ and $\mathrm{Cr}+3$ with thermodynamic equilibrium as a function of $\mathrm{pH}$ in a synthetic welding fume matrix.

Table 3. Results of chromium analyses with carbonate fusion.

\begin{tabular}{|c|c|c|c|c|c|}
\hline \multirow{2}{*}{$\begin{array}{c}\text { Sample } \\
\text { no. }\end{array}$} & \multicolumn{3}{|c|}{ Composition } & \multicolumn{2}{|c|}{ Results } \\
\hline & $\begin{array}{c}\mathrm{PbCrO} \\
(\mathrm{mg} \mathrm{Cr}+6)\end{array}$ & $\begin{array}{c}\mathrm{CrCl}_{3} \\
\left(\mathrm{mg} \mathrm{Cr}{ }^{+3}\right)\end{array}$ & $\begin{array}{l}\mathrm{Fe}_{3} \mathrm{O}_{4} \\
(\mathrm{mg})\end{array}$ & $\begin{array}{l}\text { Found } \\
\text { (mg Cr) }\end{array}$ & $\begin{array}{c}\text { Recovery } \\
(0 \% \mathrm{Cr} / \mathrm{Cr}+6)\end{array}$ \\
\hline 48 & 11.8 & & & 12.0 & 102 \\
\hline 49 & 6.85 & & 1,000 & 6.25 & 91 \\
\hline 50 & 7.63 & 33.72 & 1,000 & 21.33 & 280 \\
\hline 51 & 9.53 & 35.01 & 1,000 & 34.44 & 360 \\
\hline
\end{tabular}


companied by enhanced changes in the oxidation state (fig. 4). Thus with a sodium carbonate fusion of synthetic welding fumes, one should see a significant oxidation of the chromium which is present in low oxidation states. During sodium hydroxide fusion, oxidation by atmospheric oxygen can take place. Such reactions are represented in equation $d$. In order to demonstrate the theoretical oxidation effect, a series of synthetic welding fumes containing lead chromate and various amounts of chromic chloride and magnetite were analyzed with the carbonate fusion technique, and the results are presented in table 3 . The high recovery rates (over $300 \%$ ) verify the significance of the effect in this system.

$p H$ dependence of results of the carbonate method

The influence of $\mathrm{pH}$ on $\mathrm{Cr}^{+6}$ analysis in autoredox processes was studied in a series of synthetic welding fumes of known composition similar to that examined pre-

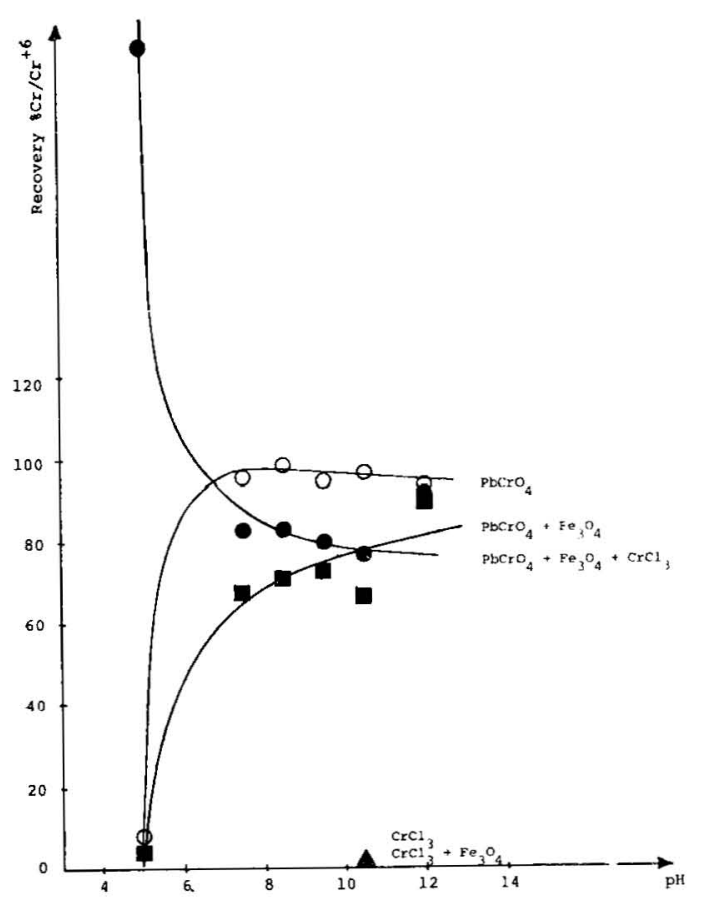

Fig. 5. Chromate recovery with the carbonate method as a function of $\mathrm{pH}$ for various matrices. viously, through the systematic addition of acid to the carbonate leaching solution.

When the carbonate method was used with samples containing pure chromate, $100 \%$ of the $\mathrm{Cr}^{+6}$ was recovered provided the $\mathrm{pH}$ was maintained at a level greater than 8 , while only $80 \%$ of the $\mathrm{Cr}^{+6}$ was recovered when magnetite was added at the same range of $\mathrm{pH}$. This reduction in $\mathrm{Cr}^{+6}$ recovery was probably a result of adhesion to the hydrated iron compounds in the precipitate, in which case the effect can be eliminated by their removal. In agreement with the previous measurements, it was found that $\mathrm{Cr}^{+3}$ is not oxidized during analysis by the carbonate method at a high $\mathrm{pH}$, a result in disagreement with the theoretical expectations (fig. 4), most probably due to the low reaction rate constant at the relatively low temperatures used in the analysis. The carbonate method was found not to be applicable at a low $\mathrm{pH}$, as the amount of $\mathrm{Cr}^{+6}$ detected was either too high or too low, depending on the sample composition. $\mathrm{Cr}^{+3}$ was also dissolved and interfered, while chromates of low solubility were not dissolved because of the low carbonate concentration (due to evaporation of carbon dioxide). The ratio of the detected chromium concentration to the original $\mathrm{Cr}^{+6}$ content of the samples $(\mathrm{Cr} /$ $\mathrm{Cr}^{+6}$ ), as a function of $\mathrm{pH}$, for the sequence of synthetic welding fume compositions studied is shown in fig. 5 , and a complete list of the analytical results is presented in table 4 (all for single determinations).

\section{EXAMPLES OF APPLICATION OF THE CARBONATE METHOD}

\section{Stainless steel welding fumes}

The carbonate method was used for the routine determination of total $\mathrm{Cr}^{+6}$ in welding fumes. The reliability of the method was verified by the analysis of actual samples of welding fumes to which known amounts of $\mathrm{Cr}^{+6}$ were added; chromium recovery in all of these cases was greater than $85 \%$, independent of chromium type, while the use of the DPC 
method yielded a chromium recovery of between 27 and $85 \%$, depending on the type of welding process. Samples consisted of Millipore cellulose filters exposed in actual work situations; one-half of each filter was used for the determination of water-soluble and total hexavalent chromium, and the other half ofor the analysis of total elemental composition. Furthermore, total $\mathrm{Cr}^{+6}$, water-soluble $\mathrm{Cr}^{+6}$ and chromium in other oxidation states was measured in samples of "reference standard" welding fumes of different compositions, produced in a welding robot used for the generation of fumes under welldefined and reproducible conditions. We observed that the total $\mathrm{Cr}^{+b}$ content of fumes appears to diminish with time, but, contrary to the assumptions of Abell (1), this is not primarily due to the filter itself, but is limited only to the water-soluble $\mathrm{Cr}^{+6}$ fraction and is mainly caused by the autoredox action of the fume matrix $\left(\mathrm{Fe}^{++}\right)$.

Water-soluble $\mathrm{Cr}^{+6}$ was measured by both the DPC technique and the carbonate method; all chromium in the water phase was found to be $\mathrm{Cr}^{+6}$. The amount and distribution of chromium (among oxidation states and fractions of different solubility) was found to be extremely dependent on values of the welding parameters. A detailed analysis of the chromium and total chemical content of welding fumes produced by different processes has been published $(22,23)$, and a study of the details of the parametric dependence of chromium in metal inert-gas (MIG) welding is under preparation (24). The general findings can be summarized by the comparison of the amount of chromium and the distribution among various oxidation states and solubilities for two common processes which represent the extremes of the physical situations encountered in welding technology involving stainless steel: manual metal arc (MMA) welding using coated electrodes and MIG. These results are shown in table 5 for stainless steel (SS) having a nominal composition of $18 \%$ chromium and $8 \%$ nickel; the total chromium content of fumes from mild steel welding is less than

Table 4. Results of chromium analyses of synthetic welding fumes of different pHs with the carbonate method.

\begin{tabular}{|c|c|c|c|c|c|c|}
\hline \multirow{2}{*}{$\begin{array}{c}\text { Sample } \\
\text { no. }\end{array}$} & \multicolumn{3}{|c|}{ Composition } & \multirow[b]{2}{*}{$\begin{array}{c}\text { Prepara- } \\
\text { tion } \\
\text { pH }\end{array}$} & \multicolumn{2}{|c|}{ Results } \\
\hline & $\underset{(\mathrm{mg}}{\mathrm{PbCrO}_{ \pm}}$ & $\begin{array}{c}\mathrm{CrCl}_{3} \\
(\mathrm{mg} \\
\mathrm{Cr}+3)\end{array}$ & $\begin{array}{c}\mathrm{Fe}_{3} \mathrm{O}_{4} \\
(\mathrm{mg})\end{array}$ & & $\begin{array}{l}\text { Found } \\
\text { (mg Cr) }\end{array}$ & $\begin{array}{c}\text { Recovery } \\
(\% \% \mathrm{Cr} / \\
\mathrm{Cr}+6)\end{array}$ \\
\hline 52 & 9.9 & 49.7 & 1,000 & 5 & 50.0 & 504 \\
\hline 53 & 9.3 & 0 & 1,000 & 5 & 0.3 & 4 \\
\hline 54 & 8.0 & 0 & 0 & 5 & 0.7 & 8 \\
\hline 55 & 8.2 & 52.8 & 1,000 & 7.5 & 6.8 & 83 \\
\hline 56 & 10.2 & 0 & 1,000 & 7.5 & 7.0 & 68 \\
\hline 57 & 8.2 & 0 & 0 & 7.5 & 7.8 & 86 \\
\hline 58 & 8.6 & 49.5 & 1,000 & 8.5 & 7.2 & 83 \\
\hline 59 & 9.1 & 0 & 1,000 & 8.5 & 6.5 & 71 \\
\hline 60 & 8.5 & 0 & 0 & 8.5 & 8.5 & 99 \\
\hline 61 & 8.5 & 49.5 & 1,000 & 9.5 & 6.8 & 80 \\
\hline 62 & 9.0 & 0 & 1,000 & 9.5 & 6.6 & 73 \\
\hline 63 & 8.4 & 0 & 0 & 9.5 & 8.0 & 95 \\
\hline 64 & 10.3 & 63.2 & 1,000 & 10.0 & 7.9 & 77 \\
\hline 65 & 7.9 & 0 & 1,000 & 10.0 & 5.3 & 67 \\
\hline 66 & 8.5 & 0 & 0 & 10.0 & 8.2 & 97 \\
\hline 67 & 9.5 & 47.0 & 0 & 10.0 & 9.8 & 103 \\
\hline 68 & 0 & 47.2 & 0 & 10.0 & 0.8 & 2 \\
\hline 69 & 0 & 49.3 & 1,000 & 10.0 & 0.8 & $\overline{2}$ \\
\hline 70 & 8.0 & 48.2 & 1,000 & 12 & 7.6 & 92 \\
\hline 71 & 8.1 & 0 & 1,000 & 12 & 7.4 & 91 \\
\hline 72 & 8.2 & 0 & 0 & 12 & 7.7 & 93 \\
\hline
\end{tabular}


Table 5. Relative content and distribution of chromium (Cr) in stainless steel welding fumes.

\begin{tabular}{lccc}
\hline $\begin{array}{l}\text { Type of } \\
\text { welding }\end{array}$ & Water-soluble $(\%)$ & Insoluble $(\%)$ & Total $(\%)$ \\
\hline & & & \\
Manual metal arc (MMA) & 0 & $0.2-2.1$ & $0.2-2.1$ \\
Cr+3 + Cr & $2.2-4.3$ & $<0.03-0.42$ & $2.2-4.3$ \\
Cr+6 & $2.2-4.3$ & $0.2-2.5$ & $2.4-6.4$ \\
Total Cr & & & \\
Metal inert gas (MIG) & 0 & & \\
argon, argon + 1 $\%$ oxygen & $0.56-13.78$ & $3.56-13.78$ \\
Cr+3 $\mathrm{Cr}$ & $0.005-0.18$ & $0.01-0.14$ & $0.02-0.32$ \\
Cr+6 & $0.005-0.18$ & $3.6-13.8$ & $4.06-13.80$ \\
Total Cr & & & \\
\hline
\end{tabular}

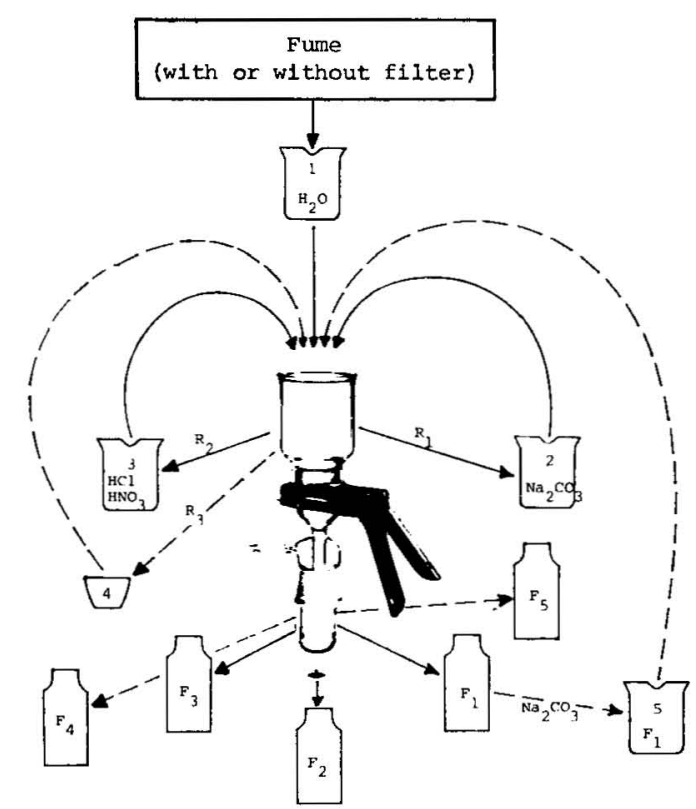

Fig. 6. Fractional analysis of welding fumes.

$0.05 \%$ for the MMA and $0.005 \%$ for the MIG method.

Of the chromium occurring in fumes from MMA/SS processes, $5-33 \%$ appears as either metallic chromium or $\mathrm{Cr}^{+3}$, which are totally insoluble in water, while $67-95 \%$ is in the form of $\mathrm{Cr}^{+6}$, of which between $0-13 \%$ is insoluble in water. For MIG/SS processes (with argon or argon with $1 \%$ oxygen), $98.00-99.86 \%$ of the chromium present is in the form of $\mathrm{Cr}^{+3}$ or metallic chro- mium, which is completely insoluble, while $0.14-2.00 \%$ appears as $\mathrm{Cr}^{+6}$, of which $60-90 \%$ is insoluble in water.

Methods for determining the chemical composition of welding fumes including hexavalent chromium content and fractionation into elements according to solubility

The toxicity of many of the elements which can possibly appear in welding fumes (lead, chromium, nickel, tungsten, zinc, barium) is greatly dependent on the chemical compounds in which these elements occur. The permitted hygienic exposure levels (TVL's) for the individual compounds are frequently given in terms of both the relative solubility of the substances and the oxidation state of the elements. The evaluation of the burden placed on the welder by exposure to the fumes from various welding processes must therefore be based on a detailed analysis of the chemical composition of the fumes together with a determination of the elemental oxidation state and relative solubility. Hygienic samples frequently provide only limited amounts of material to work with (typically $1-5 \mathrm{mg}$ ) and therefore place additional demands on the analysis technique and make any standard fractionation process subject to significant errors.

Synthetic welding fumes consisting of $\mathrm{Fe}_{3} \mathrm{O}_{4}(57 \%), \mathrm{PbCrO}_{4}(2.34 \%), \mathrm{K}, \mathrm{Cr}_{2} \mathrm{O}_{7}$ $(2.33 \%), \mathrm{Cr}_{2} \mathrm{O}_{3}(11.73 \%)$, NiO $(11.67 \%)$, $\mathrm{NiCl}_{3}, 6 \mathrm{H}_{2} \mathrm{O}(2.48 \%)$, and $\mathrm{MnO}_{2}(11.73 \%)$, 
corresponding to a typical distribution of elements and solubilities, were analyzed for chemical composition and solubilities by means of a procedure which is schematically shown in fig. 6 . This procedure is considered to be optimal in terms of contamination and other problems and to have the minimum possible number of manipulations consistent with the recirculation of compounds through the preparation apparatus.

The specific steps of the procedure are as follows:

1. The weighed sample (or filter with known sample) is transfered to a $100-\mathrm{ml}$ beaker, $25.0 \mathrm{ml}$ of ion exchanged water is added, and the sample agitated at room temperature for $30 \mathrm{~min}$. The resulting solution, together with the suspended matter, and the filter (if present) is transferred to a vacuum filter fitted with a 0.4 membrane filter. The filtrate $\left(F_{1}\right)$ is separated for further analysis, and the remainder $\left(R_{1}\right)$, including the 0.4 membrane filter, is returned to the original beaker.

2. To the beaker containing $R_{1}$ is now added $25.0 \mathrm{ml}$ of a $7 \%$ sodium carbonate solution, which is then raised to the boiling point and set aside to cool. The contents of the beaker are now filtered as in step 1, the filtrate $F_{2}$ separated for further analysis, and the remainder $\left(R_{2}\right)$ returned to the original beaker (including all filters).

3. Filters and precipitates $R_{2}$ are now dissolved by boiling in nitric/hydrochloric acid and evaporated to dryness, and after sufficient cooling the residue dissolved in $25.0 \mathrm{ml}$ of ion exchanged water. Any residue at this point (not dissolved by additional warming) is filtered once more, filters and residue forming $R_{3}$, which is retained for further analysis, as is filtrate $\mathrm{F}_{3}$.

4. Residue $R_{3}$ is dried and ashed by incineration with hydrofluoric acid, or acidic or basic or, if necessary, oxidizing fusion. The sample is then filtered, if necessary, yielding $\mathrm{F}_{4}$ for further analysis. In general $R_{2}$ is soluble in acid, whereby the watersoluble fractions $F_{3}$ and $R_{3}$ are eliminated.

5. Water-soluble chromium as found in welding fumes consists entirely of $\mathrm{Cr}^{+6}$; therefore the AAS analysis of total chromium in $F_{1}$ can be considered sufficient to determine the water-soluble $\mathrm{Cr}^{+6}$ content of this material. In the case of uncertainty, however, $F_{1}$ can be analyzed specifically for $\mathrm{Cr}^{+6}$ by means of the DPC method or upon the addition of solid sodium carbonate to all or part of $F_{1}$, whereby, after boiling, cooling and filtration, the resulting $\mathrm{F}_{5}$ is analyzed for $\mathrm{Cr}^{+6}$.

6. $F_{1}, F_{2}, F_{3}, F_{4}$, and $F_{5}$ are thereafter analyzed for the desired elemental content by means of AAS.

Liquid loss during boiling (steps 2 and 3 ), together with insufficient rinsing of the various filters, will probably represent the most significant sources of error, or a mixing of the different fractions.

Analysis of a long series of synthetic welding fumes shows that, with the single exception of nickel chloride $\left(\mathrm{NiCl}_{3}\right)$ (aqueous), the initial components are recovered in the proper fractions within the expected error limits $(10 \%)$; the low $\mathrm{NiCl}_{3}$ recovery $(69 \%)$ is probably due a different hydration than expected.

The chromic acid used proved to be insoluble in acid and could first be dissolved by oxidizing alkali fusion. Since actual welding fumes are normally acid-soluble, it can be concluded that $\mathrm{Cr}^{+3}$ appears either as a hydrated sesquioxide or as picotite $\left(\mathrm{FeO}-\mathrm{Cr}_{2} \mathrm{O}_{3}\right)$. The latter is most probably the case since $\mathrm{X}$-ray diffraction analysis of welding fumes containing chromium show only the magnetite structure $\left(\mathrm{Fe}_{3} \mathrm{O}_{4}\right)$ (which is identical to picotite in crystal structure) with a possible line shift in the direction expected for increasing chromium content.

The results from synthetic welding fume analysis are presented in table 6. Fumes from actual welding processes, produced under well-defined conditions in a welding robot, were also analyzed according to the described technique; the results are assembled in table 7 . It should be noted that the relative distribution of chromium among oxidation states and solubility fractions is extremely dependent on the values of the welding parameters (current, voltage, shielding gas, arc length) as indicated.

In contrast to the previous results (table 5 - where measurements have been made 
Table 6. Elemental distribution of synthetic welding fumes a in a fractional analysis. (Continued on the next page)

\begin{tabular}{|c|c|c|c|c|c|c|c|c|c|}
\hline \multirow[b]{2}{*}{ Fraction ${ }^{b}$} & \multicolumn{3}{|c|}{ Chromium (mg) } & \multicolumn{3}{|c|}{ Lead (mg) } & \multicolumn{3}{|c|}{ Potassium (mg) } \\
\hline & Found & $\begin{array}{c}\text { Ex- } \\
\text { pected }\end{array}$ & $\begin{array}{l}\% \text { Re- } \\
\text { covery }\end{array}$ & Found & $\begin{array}{l}\text { Ex- } \\
\text { pected }\end{array}$ & $\begin{array}{l}\% \text { Re- } \\
\text { covery }\end{array}$ & Found & $\begin{array}{c}\text { Ex- } \\
\text { pected }\end{array}$ & $\begin{array}{l}\% \text { Re- } \\
\text { covery }\end{array}$ \\
\hline$\underset{\mathbf{B}}{F_{1} \text { (water soluble) }}$ & $\begin{array}{l}0.30 \\
0.049\end{array}$ & $\begin{array}{l}0.33 \\
0.038\end{array}$ & $\begin{array}{r}91 \\
129\end{array}$ & $\begin{array}{l}0.003 \\
0.003\end{array}$ & $\begin{array}{l}0 \\
0\end{array}$ & $=$ & $\begin{array}{l}0.285 \\
0.039\end{array}$ & $\begin{array}{l}0.326 \\
0.038\end{array}$ & $\begin{array}{r}87 \\
103\end{array}$ \\
\hline $\mathrm{F}_{\mathbf{B}}^{\mathrm{A}}$ (sodium carbonate soluble) & $\begin{array}{l}0.166 \\
0.023\end{array}$ & $\begin{array}{l}0.198 \\
0.023\end{array}$ & $\begin{array}{r}84 \\
100\end{array}$ & $\begin{array}{l}0.21 \\
0.04\end{array}$ & $\begin{array}{l}0 \\
0\end{array}$ & $=$ & $\begin{array}{l}0.088 \\
0.040\end{array}$ & $\begin{array}{l}0 \\
0\end{array}$ & $\overline{-}$ \\
\hline$\underset{\mathbf{B}}{F_{3}(\text { acid soluble) }}$ & $\begin{array}{l}0.079 \\
0.000\end{array}$ & $\begin{array}{l}0-4.23 \\
0-0.50\end{array}$ & $\begin{array}{l}(2) \\
(2)\end{array}$ & $\begin{array}{l}0.645 \\
0.05\end{array}$ & $\begin{array}{l}0.79 \\
0.093\end{array}$ & $\begin{array}{l}82 \\
54\end{array}$ & $\begin{array}{l}0.034 \\
0.021\end{array}$ & $\begin{array}{l}\mathbf{0} \\
\mathbf{0}\end{array}$ & $=$ \\
\hline$\underset{\mathrm{B}}{\mathbf{F}_{4}}$ & $\begin{array}{l}4.07 \\
0.46\end{array}$ & $\begin{array}{l}0-4.23 \\
0-0.50\end{array}$ & $\begin{array}{l}(96) \\
(92)\end{array}$ & 二 & $=$ & 二 & $=$ & $=$ & 二 \\
\hline$\underset{\mathrm{B}}{\operatorname{Total}}\left(F_{1}+F_{2}+F_{3}+F_{4}\right)$ & $\begin{array}{l}4.62 \\
0.54\end{array}$ & $\begin{array}{l}4.76 \\
0.56\end{array}$ & $\begin{array}{l}97 \\
96\end{array}$ & $\begin{array}{l}0.86 \\
0.09\end{array}$ & $\begin{array}{l}0.79 \\
0.093\end{array}$ & $\begin{array}{r}109 \\
97\end{array}$ & $\begin{array}{l}\mathbf{0 . 4 0 7} \\
0.10\end{array}$ & $\begin{array}{l}0.326 \\
0.038\end{array}$ & $\begin{array}{l}125 \\
263\end{array}$ \\
\hline
\end{tabular}

a Synthetic welding fumes: $\mathrm{Fe}_{3} \mathrm{O}_{4}(57.7 \%), \mathrm{PbCrO}_{4}(2.34 \%), \mathrm{K}_{2} \mathrm{Cr}_{2} \mathrm{O}_{7}(2.33 \%), \mathrm{Cr}_{2} \mathrm{O}_{3}(11.73 \%)$, $\mathrm{NiO}(11.67 \%), \mathrm{NiCl}_{3}, 6 \mathrm{H}_{2} \mathrm{O}(2.48 \%), \mathrm{MnO}_{2}(11.73 \%)$.

b A: $52.73 \mathrm{mg}, \mathrm{B}: 6.21 \mathrm{mg}$.

Table 7. Elemental distribution of welding fumes from stainless steel in a fractional analysis. (Continued on the next page)

\begin{tabular}{|c|c|c|c|c|c|c|c|c|c|c|c|}
\hline \multirow{3}{*}{ Sample } & & & & \multicolumn{4}{|c|}{ Chromium (\%) } & \multicolumn{4}{|c|}{ Nickel (\%) } \\
\hline & \multicolumn{3}{|c|}{$\begin{array}{c}\text { Welding } \\
\text { parameters }\end{array}$} & \multirow{2}{*}{\multicolumn{2}{|c|}{$\begin{array}{c}\text { Sodium } \\
\text { car- } \\
\text { bonate } \\
\text { soluble } \\
\left(\mathbf{F}_{2}\right)\end{array}$}} & \multirow{2}{*}{$\begin{array}{c}\begin{array}{c}\text { Acid } \\
\text { soluble }\end{array} \\
\left(F_{3}\right)\end{array}$} & \multirow{2}{*}{$\begin{array}{l}\text { Total } \\
\text { (F) }\end{array}$} & \multirow{2}{*}{$\begin{array}{c}\begin{array}{c}\text { Water } \\
\text { soluble }\end{array} \\
\left(\mathrm{F}_{1}\right)\end{array}$} & \multirow{2}{*}{$\begin{array}{c}\text { Sodium } \\
\text { car- } \\
\text { bonate } \\
\text { soluble } \\
\left(\mathrm{F}_{2}\right)\end{array}$} & \multirow{2}{*}{$\begin{array}{c}\text { Acid } \\
\text { soluble } \\
\left(\mathrm{F}_{3}\right)\end{array}$} & \multirow{2}{*}{$\begin{array}{l}\text { Total } \\
\text { (F) }\end{array}$} \\
\hline & Amp & Volt & $\mathrm{mm}_{\mathbf{l}}$ & & & & & & & & \\
\hline $\begin{array}{l}\text { MO } 17{ }^{b} \\
\text { MO } 18 \\
\text { MO } 19 \\
\text { MO } 20 \\
\text { MO } 21 \\
\text { MO } 22 \\
\text { MO } 23^{d} \\
\text { MO } 24\end{array}$ & $\begin{array}{l}170 \\
170 \\
110 \\
240 \\
250 \\
250 \\
285 \\
235\end{array}$ & $\begin{array}{l}16.5 \\
16.5 \\
16.8 \\
16.0 \\
26.5 \\
26.3 \\
26.3 \\
25.5\end{array}$ & $\begin{array}{l}1.8 \\
1.8 \\
2.8 \\
0.9 \\
2.5-3.8 \\
7.5-8.8 \\
1.9-2.5 \\
4.4-5.0\end{array}$ & $\begin{array}{l}0.31 \\
0.38 \\
0.24 \\
0.40 \\
0.17 \\
0.07 \\
0.11 \\
0.03\end{array}$ & $\begin{array}{l}0.096 \\
0.120 \\
0.083 \\
0.098 \\
0.113 \\
0.091 \\
0.087 \\
0.045\end{array}$ & $\begin{array}{l}4.70 \\
3.82 \\
4.93 \\
3.56 \\
4.96 \\
5.08 \\
4.18 \\
7.55\end{array}$ & $\begin{array}{l}\mathbf{5 . 1 1} \\
\mathbf{4 . 3 2} \\
\mathbf{5 . 2 5} \\
4.06 \\
\mathbf{5 . 2 4} \\
\mathbf{5 . 2 4} \\
4.38 \\
\mathbf{7 . 6 3}\end{array}$ & $\begin{array}{l}0.151 \\
0.173 \\
0.109 \\
0.159 \\
0.089 \\
0.044 \\
0.067 \\
0.025\end{array}$ & $\begin{array}{l}0.024 \\
0.021 \\
0.026 \\
0.022 \\
0.021 \\
0 \\
0.010 \\
0.005\end{array}$ & $\begin{array}{l}4.49 \\
4.57 \\
3.11 \\
4.83 \\
4.53 \\
2.72 \\
4.39 \\
2.77\end{array}$ & $\begin{array}{l}4.67 \\
4.76 \\
3.25 \\
5.01 \\
4.64 \\
2.76 \\
4.47 \\
2.80\end{array}$ \\
\hline
\end{tabular}

a Electrode: 3RS17 $1.6 \mathrm{~mm}^{\varnothing}$ (argon $+1 \%$ oxygen).

b Short arc transfer.

c Drop transfer.

d Spray transfer.

without the fractionation technique), an analysis of table 7 shows a lower total chromium content and, especially for short arc welding, an increased amount of watersoluble $\mathrm{Cr}^{+6}$. The data of table 7 are based on a larger diameter wire $(1.6 \mathrm{~mm})$ of the same type as used in table $5(1.2 \mathrm{~mm})$, and this variation may also account for some of the differences found. The analysis also unexpectedly showed that the fumes contain carbonate-soluble manganese and nickel compounds and that the manganese content and its distribution among the solubility fractions is extremely parameter dependent. The distribution of nickel and manganese among the various solubility fractions has not previously been investigated for these fume types.

\section{Additional uses of the carbonate method $^{3}$}

The applicability of the carbonate method for the analysis of $\mathrm{Cr}^{+6}$ in biological mate-

3 For an example of an industrial application of a similar method see Bombach and Luft (6). 
Table 6. (continued)

\begin{tabular}{|c|c|c|c|c|c|c|c|c|c|}
\hline \multirow[b]{2}{*}{ Fraction ${ }^{b}$} & \multicolumn{3}{|c|}{ Nickel (mg) } & \multicolumn{3}{|c|}{ Manganese (mg) } & \multicolumn{3}{|c|}{ Iron (mg) } \\
\hline & Found & $\begin{array}{c}\text { Ex- } \\
\text { pected }\end{array}$ & $\begin{array}{l}\% \mathrm{Re}- \\
\text { covery }\end{array}$ & Found & $\begin{array}{c}\text { Ex- } \\
\text { pected }\end{array}$ & $\begin{array}{l}\% \text { Re- } \\
\text { covery }\end{array}$ & Found & $\begin{array}{c}\text { Ex- } \\
\text { pected }\end{array}$ & $\begin{array}{l}\% \text { Re-- } \\
\text { covery }\end{array}$ \\
\hline $\mathbf{F}_{\mathbf{B}}$ (water soluble) & $\begin{array}{l}0.222 \\
0.026\end{array}$ & $\begin{array}{l}0.32 \\
0.038\end{array}$ & $\begin{array}{l}69 \\
68\end{array}$ & $\begin{array}{l}0.0068 \\
0.018\end{array}$ & $\begin{array}{l}0 \\
0\end{array}$ & - & $\begin{array}{l}<0.0005 \\
<0.0005\end{array}$ & $\begin{array}{l}0 \\
0\end{array}$ & $=$ \\
\hline${ }_{\mathrm{B}}^{\mathrm{F}_{2}}$ (sodium carbonate soluble) & $\begin{array}{l}0.035 \\
0.013\end{array}$ & $\begin{array}{l}0 \\
0\end{array}$ & 二 & $\begin{array}{l}0.013 \\
0.0073\end{array}$ & $\begin{array}{l}\underset{0}{0} \\
0\end{array}$ & 二 & $\begin{array}{r}0.011 \\
0.016\end{array}$ & $\begin{array}{l}0 \\
0\end{array}$ & $=$ \\
\hline${ }_{\mathrm{B}}^{\mathrm{F}_{3}}$ (acid soluble) & $\begin{array}{l}4.45 \\
0.52\end{array}$ & $\begin{array}{l}4.83 \\
0.57\end{array}$ & $\begin{array}{l}92 \\
91\end{array}$ & $\begin{array}{l}4.00 \\
0.47\end{array}$ & $\begin{array}{l}3.91 \\
0.46\end{array}$ & $\begin{array}{l}102 \\
102\end{array}$ & $\begin{array}{c}20.4 \\
2.85\end{array}$ & $\begin{array}{l}22.0 \\
2.59\end{array}$ & $\begin{array}{r}93 \\
110\end{array}$ \\
\hline${ }_{\mathrm{B}}^{\mathrm{F}_{4}}$ & 二 & 二 & $=$ & $=$ & $=$ & $=$ & 二 & $=$ & $=$ \\
\hline$\underset{\mathrm{B}}{\mathrm{A}} \underset{\mathrm{Total}}{\mathrm{A}}\left(\mathbf{F}_{1}+\mathbf{F}_{2}+\mathbf{F}_{3}+\mathbf{F}_{4}\right)$ & $\begin{array}{l}4.71 \\
0.56\end{array}$ & $\begin{array}{l}5.15 \\
0.61\end{array}$ & $\begin{array}{l}91 \\
92\end{array}$ & $\begin{array}{l}4.02 \\
0.48\end{array}$ & $\begin{array}{l}3.91 \\
0.46\end{array}$ & $\begin{array}{l}103 \\
104\end{array}$ & $\begin{array}{r}20.4 \\
2.9\end{array}$ & $\begin{array}{c}22.0 \\
2.59\end{array}$ & $\begin{array}{r}93 \\
110\end{array}$ \\
\hline
\end{tabular}

a Synthetic welding fumes: $\mathrm{Fe}_{3} \mathrm{O}_{4}(57.7 \%), \mathrm{PbCrO}_{4}(2.34 \%), \mathrm{K}_{2} \mathrm{Cr}_{2} \mathrm{O}_{7}(2.33 \%), \mathrm{Cr}_{2} \mathrm{O}_{3}(11.73 \%)$, $\mathrm{NiO}(11.67 \%), \mathrm{NiCl}_{3}, 6 \mathrm{H}_{2} \mathrm{O}(2.48 \%), \mathrm{MnO}_{2}(11.73 \%)$.

b A: $52.73 \mathrm{mg}, \mathrm{B}: 6.21 \mathrm{mg}$.

Table 7. (continued)

\begin{tabular}{|c|c|c|c|c|c|c|c|c|c|c|c|}
\hline \multirow{3}{*}{ Sample } & & & & \multicolumn{4}{|c|}{ Manganese $(\%)$} & \multicolumn{4}{|c|}{ Iron $(\%)$} \\
\hline & \multicolumn{3}{|c|}{$\begin{array}{c}\text { Welding } \\
\text { parameters }\end{array}$} & \multirow{2}{*}{\multicolumn{2}{|c|}{$\begin{array}{c}\text { Sodium } \\
\text { car- } \\
\text { le bonate } \\
\begin{array}{c}\text { soluble } \\
\left(\mathbf{F}_{2}\right)\end{array}\end{array}$}} & \multirow{2}{*}{$\begin{array}{c}\text { Acid } \\
\text { soluble } \\
\left(\mathbf{F}_{8}\right)\end{array}$} & \multirow{2}{*}{$\begin{array}{l}\text { Total } \\
\text { (F) }\end{array}$} & \multirow{2}{*}{$\begin{array}{c}\text { Water } \\
\text { soluble } \\
\left(F_{1}\right)\end{array}$} & \multirow{2}{*}{$\begin{array}{c}\text { Sodium } \\
\text { car- } \\
\text { bonate } \\
\text { soluble } \\
\left(\mathbf{F}_{2}\right)\end{array}$} & \multirow{2}{*}{$\begin{array}{c}\text { Acid } \\
\text { soluble }\end{array}$} & \multirow{2}{*}{$\begin{array}{r}\text { Total } \\
\text { (F) }\end{array}$} \\
\hline & Amp & Volt & $\mathrm{mm}$ & & & & & & & & \\
\hline $\begin{array}{l}\text { MO } 17{ }^{\mathrm{b}} \\
\text { MO } 18 \\
\text { MO } 19 \\
\text { MO } 20 \\
\text { MO } 21 \\
\text { MO } 22 \\
\text { MO } 22 \\
\text { MO } 23 \\
\text { MO } 24 \\
\text { d }\end{array}$ & $\begin{array}{l}170 \\
170 \\
110 \\
240 \\
250 \\
250 \\
285 \\
235\end{array}$ & $\begin{array}{l}16.5 \\
16.5 \\
16.8 \\
16.0 \\
26.5 \\
26.3 \\
26.3 \\
25.5\end{array}$ & $\begin{array}{l}1.8 \\
1.8 \\
2.8 \\
0.9 \\
2.5-3.8 \\
7.5-8.8 \\
1.9-2.5 \\
4.4-5.0\end{array}$ & $\begin{array}{l}0.25 \\
0.31 \\
0.42 \\
0.24 \\
0.18 \\
0.27 \\
0.23 \\
0.22\end{array}$ & $\begin{array}{l}0.149 \\
0.151 \\
0.557 \\
0.299 \\
0.115 \\
0.105 \\
0.135 \\
0.076\end{array}$ & $\begin{array}{r}11.8 \\
9.1 \\
15.3 \\
9.5 \\
9.2 \\
15.1 \\
9.0 \\
12.7\end{array}$ & $\begin{array}{r}12.2 \\
9.6 \\
16.3 \\
10.0 \\
9.5 \\
15.5 \\
9.4 \\
13.0\end{array}$ & $\begin{array}{l}0 \\
0 \\
0.02 \\
0.01 \\
0 \\
0.01 \\
0 \\
0\end{array}$ & $\begin{array}{l}0.05 \\
0.06 \\
0.09 \\
0.08 \\
0.05 \\
0.02 \\
0.05 \\
0.03\end{array}$ & $\begin{array}{l}37.0 \\
35.9 \\
29.3 \\
35.5 \\
37.1 \\
34.9 \\
34.5 \\
35.8\end{array}$ & $\begin{array}{l}37.1 \\
36.0 \\
29.4 \\
35.6 \\
37.2 \\
34.9 \\
34.6 \\
35.8\end{array}$ \\
\hline
\end{tabular}

a Electrode: 3RS17 $1.6 \mathrm{~mm}^{\varnothing}$ (argon $+1 \%$ oxygen).

b Short arc transfer.

c Drop transfer.

d Spray transfer.

rial was studied in a series of preliminary measurements. Towards this end, a sample was synthesized by the mixing of $19 \mathrm{mg}$ of $\mathrm{Cr}^{+6}$ (as potassium dichromate) with $5 \mathrm{ml}$ of horse serum; $86 \%$ of the initial $\mathrm{Cr}^{+6}$ was recovered with the carbonate method (compared to $101 \%$ in the absence of the serum).

For comparison, Blomquist (5) found that only $2.5 \%$ of the initial $\mathrm{Cr}^{+6}$ was recovered when the DPC method was used to analyze a sample consisting of $15 \mu \mathrm{g}$ serum albumin and $4 \mu \mathrm{g} \mathrm{Cr}^{+6}$. Thus, in numerous analytical situations with a need for the measurement of the distribution of chromium among the various oxidation states, the carbonate method would appear to be a practical solution, requiring only slight modification depending on the specific type of analysis required. The method has in fact been used for industrial hygiene measurements in the tanning and timber impregnation industries, which provide for other types of complex, organic matrices, as well as for process control and process development, e.g., control of the organic fixation of wood preservatives $\left(\mathrm{Cr}^{+6}\right.$ to 
$\mathrm{Cr}^{+3}$ ) and the indirect control of $\mathrm{Cr}^{+3}$ content of galvanizing baths.

\section{SUMMARY AND CONCLUSIONS}

Because of increasing concern for the health of workers, especially with respect to dermatitis and allergy-inducing substances active even in trace amounts, there is a specific need for reliable and sensitive analytical methods for the determination of the composition of industrial atmospheres. One specific need is for a method for the detection of $\mathrm{Cr}^{+6}$ compounds in fractions with different water solubilities, the demands of which appear not to be met by any previously used methods.

The carbonate leaching method described in this report represents a simple technique for the routine determination of total $\mathrm{Cr}^{+6}$ in complex matrices, of which welding fumes is a practical example. When used with synthetic welding fumes of known composition, more than $80 \%$ of the original, slightly soluble and insoluble chromate can be recovered (in contrast to the DPC method for which recovery can be as low as $1 \%$ ). The remaining $20 \%$ of $\mathrm{Cr}^{+6}$ can eventually be recovered through the addition of an extra wash step so that any $\mathrm{Cr}^{+6}$ adsorbed in the remaining precipitates can be liberated. The recovery rate achieved is, in any case, satisfactory for hygienic measurements (where other more significant errors can occur), so that the uncomplicated technique can be retained without modification for such application.

It is postulated that for each sample composition, determined by the presence of autoredox systems and the distribution of chromium among various oxidation states, there is a single well-defined $\mathrm{pH}$ for which the system will be in thermodynamic equilibrium. Preparation at a lower $\mathrm{pH}$ should be accompanied by a reduction of some unknown fraction of the $\mathrm{Cr}^{+6}$ initially present, while preparation at a higher $\mathrm{pH}$ could lead to the oxidation of chromium in lower oxidation states. Both situations were investigated with the use of synthetic welding fumes, and the expected change in oxidation state when the carbonate method was used at a high $\mathrm{pH}$ was not found to take place, most probably due to the low reaction rate constant at the low temperatures (below $100^{\circ} \mathrm{C}$ ) used. Thus the carbonate method can be used to determine the total $\mathrm{Cr}^{+6}$ content of welding fumes, a type of matrix for which other wet chemical methods have been shown to be unsuitable.

Pilot studies using this method on these aerosols indicate that the nature of the metallic compounds actually occurring in welding fumes varies greatly as a function of the welding method and welding parameter, and the possibility of a similar variation of biological activities for these substances is therefore implied. Extended studies to determine the exact nature of such effects are currently underway.

\section{ACKNOWLEDGMENT}

The authors would like to express their appreciation for the continuous encouragement and extensive technical support given by $\mathrm{H}$. Berg (Kemitechnic).

This work was partially financed by the Danish Council for Scientific and Technicial Research and the Council of Technology.

\section{REFERENCES}

1. ABELL, M. T. and CARLBERG, J. R. A simple reliable method for the determination of airborne hexavalent chromium. Am. ind. hyg. assoc. j. 35 (1974) 229-233.

2. AKSELSSON, R. K., DESAEDELEER, G. G., JOHANSSON, T. B. and WINCHESTER, J. W. Particle size distribution and human deposition of trace metals in indoor work environments. Ann occup. hyg. 19 (1977) $76-82$.

3. AMERICAN PUBLIC HEALTH ASSOCIATION. Standard methods for the examination of water and waste water (14th ed.). Washington, DC 1975.

4. BAETJER, A. M., DAMRON, C. M., CLARK, J. $H$. and BUDACZ, V. Reaction of chromium compounds with body tissue and their constituents. Arch. ind. health 12 (1955) 258.

5. BLOMQUIST, G. Analysis and sampling 
of hexavalent chromium: I. Investigation of diphenylcarbizide method (Study report 1977: 32). Arbetarsskyddstyrelsen, Stockholm 1977 (in Swedish).

6. BOMBACH, H. and LUFT, B. Determination of chromium and iron of different oxidation states in ferrochromium slags. Neue Hütte 21 (1976): 11, 685-687.

7. DAVIES, J. M. Lung cancer mortality of workers making chrome pigments. Lancet Feb. 18 (1978) 394.

8. FREIER, R. K. Aqueous solutions (vol I). Waleer de Gruyter, Berlin-New York 1976.

9. FREIER, R. K. Aqueous solutions (vol II). Waleer de Gruyter, Berlin-New York 1978.

10. HEDENSTEDT, A., JENSSEN, D., LIDESTEN, B.-M., RAMEL, C., RANNUG, U. and STERN, R. M. Mutagenicity of fume particles from stainless steel welding. Scand. j. work environ. \& health 3 (1977) $203-211$.

11. KALLIOMÄKI, P.-L., ALANKO, K., KORHONEN, O., MATTSSON, T., VAARANEN, V. and KOPONEN, M. Amount and distribution of welding fume contaminants among arc welders. Scand. $j$. work environ. and \& health 4 (1978) 122-130.

12. LANGARD, S. and NORSETH, T, A cohort study of bronchial carcinomas in workers producing chromate pigments. $B r$. $j$. ind. med. 32 (1975) $62-65$.

13. LANGARD, S. and NORSETH, T. Cancer in the gastrointestinal tract in chromate pigment workers. In: Proceedings of the $X I X$ international congress of medicine, Dubrovnik September 1978.

14. LAUTNER, G. M., CARVER, J. C. and KONZEN, R. B. Measurement of chromium VI and chromium III in stainless steel welding fumes with electron spectroscopy for chemical analysis and neutron activation analysis. Am. ind. hyg. assoc. j. 39 (1978) 8.

15. MAXILD, J., ANDERSEN, M., KIEL, P. and STERN, R. M. Mutagenicity of fume particles from metal arc welding on stainless steel in the salmonella/microsome test. Mutat. res. 56 (1978) 235-243.

16. NATIONAL ACADEMY OF SCIENCES. Chromium: The medical and biological effects of environmental pollutants. Washington, DC 1974.
17. NATIONAL INSTITUTE FOR OCCUPATIONAL SAFETY AND HEALTH. Criteria for a recommended standard: Occupational exposure to chromium (VI). U.S. Department of Health, Education and Welfare, Washington, DC 1975, pp. 76-129.

18. PETRILLI, F. and DE FLORA, S. Toxicity and mutagenicity of hexavalent chromium and salmonella typhimurium. $A p p$. Environ. Microbio. 33 (1977) 804-809.

19. STERN, R. M. A chemical, physical and biological assay of welding fume: Part I. Fume characteristics (Publication 77.05). The Danish Welding Institute, Glostrup 1977.

20. STERN, R. M. Chemical, physical and biological assay of welding fume: Part II. Implications of positive mutagenic tests (SVC publication 77.08). The Danish Welding Institute, Glostrup 1977.

21. STERN, R. M. Possible inadequacy of Ames test systems for metallic aerosols (Publication 78.11). The Danish Welding Institute, Copenhagen 1978.

22. STERN, R. M. Production and characterization of a reference standard welding fume: Part I. Factors effecting fume production (SF 76.05). The Danish Welding Institute. Glostrup 1976.

23. STERN, R. M. Production and characterization of a reference standard welding fume: Part II. The chemistry of welding smoke and its variation with welding process and process parameter (SF 78.01). The Danish Welding Institute, Glostrup 1978.

24. STERN, R. M. Hexavalent chromium and other toxic substances in welding fumes: Occurrence and possible methods of engineering controls. The Danish Welding Institute, Glostrup. (in press)

25. STETTLER, L., GROTH, D. H. and MAKAY, G. R. Identification of stainless steel welding fume particles in human lung and environmental samples using electron probe microanalysis $A m$. ind. hyg. assoc. j. 38 (1977) 76-82.

26. VENITT, S. and LEVY, L. S. Mutagenicity of chromates in bacteria and its relevance to chromate carcinogenesis. Nature 250 (1974) 493-495. 